UDC 821.111(73).09-1 ПаунА E.

\author{
Svetlana Nedeljkov* \\ University of New Brunswick, \\ English Language Department, \\ Fredericton, Canada
}

\title{
FROM ECONOMICS TO FASCISM: EZRA POUND'S SHIFT TOWARDS INCLUSIVITY
}

\begin{abstract}
Ezra Pound was a literary activist who devoted his life to writing, translating, and educating those willing to be initiated to modernist writing. He was also a poet of megalomaniacal ideas, believing that he could change the world by educating "the nation." Seeking a solution for the contemporary socio-political issues, Pound started equating Jews with usury and blaming them for the world's ills. These views consequently pushed him over the edge, towards fascism. The aim of this paper, therefore, is to investigate how Pound's aim to educate readers became an effort to re-educate them by exposing them to his fascist and anti-Semitic views, and explore whether The Cantos, which Pound sets up to be aesthetically and semantically "open," consequently turns into a "closed" fascist manifesto, mirroring Pound's political agenda.
\end{abstract}

Key words: Ezra Pound, The Cantos, teaching pedagogy, fascism, closed and open text

After the disillusionment that followed World War I, Pound's dissatisfaction with the economic ills of the world became increasingly visible in The Cantos. A believer in conspiracy theories, Pound attributed most of the world's economic ills to an international scheme of Jewish bankers "who controlled the British crown and had 'succeeded in duping the government of the United States"' (qtd. in Doberman 2000: 47). By turning his poetry

E-mail address: mementomori123@hotmail.com. The author is a PhD candidate. 
to economics (Doberman 2000: 47) in his avant-garde and paratactic manner, Pound narrowed the circle of readers for The Cantos. Due to this, the already "impenetrable" epic (Stoicheff 1995: 180) gained yet another aspect which challenged not only readers' knowledge of mythology and disparate languages, but also their awareness of contemporary economic world order. As an act of defiance against the "trick and money" that "damned" the golden America (Stoicheff 1995: 68), as William Carlos Williams pronounces it, Pound shifts the focus of the epic from aesthetically breathtaking passages of his early Cantos to usury which "slayeth the child in the womb" (45/230).

Given that Pound's textbooks as well as his poetry highlight a poet who approaches his work as a teacher deeply concerned with edifying his readers throughout his life, taking this aspect of his life into consideration seems necessary. As suggested by "Make it New," Pound's collection of essays, the purpose of art is to teach "its readers how to read, the aim of which is to give them a more sophisticated historical and social awareness (Bettridge 2005: 190)." Critics such K.K. Ruthven, Gail McDonald and Mary DeRachewiltz, moreover, discuss the poet's effort to educate his students at the "Ezuversity" (Pound's unofficial locus of teaching): "Pound thought he would save them [the students of Ezuversity] valuable time in offering them helpful shortcuts: for why else spend "30 years...trying to reorganize the study of literature' if not in the hope of making it 'of some use to the student (qtd. in Ruthven 1990: 33)." Indeed, the epigraph in Guide to Kulchur provides evidence of Pound's devotion to imparting his knowledge: "[t]his book is not written for the over-fed. It is written for men who have not been able to afford an university education or for young men, whether or not threatened with universities, who want to know more at the age of fifty than I know today, and whom I might conceivably aid to that object (Pound 1970: 6)."

Pound's textbooks - Guide to Kulchur, $A B C$ of Reading, How to Read, to name but three - exhibit how consciously he viewed his role as a teacher of cultural values as well as of different traditions, languages and histories; on the other hand, these textbooks as well as his poetry show how obdurate he seemed to have been in his reading of history - a single-mindedness that eventually became manifest in his fervent support of fascist sociopolitics and economics. Pound's resentment of those who exploit their power in order to take the money out of production becomes glaringly obvious in "Canto XLV," where readers are instructed that: "WITH 
USURA/ wool comes not to market/ sheep bringeth no gain with usura" (45/229). Due to this and similar claims, Alec Marsh finds Pound an "early believer in the quantity theory of money" who insisted that producers should not force natural values and production to measure up to prior monetary debts (Marsh 1998: 76). Marsh further highlights that the usury system "undermines ANY nation" since:

The institution of interest divides the 'fruits of labor and nature' before the harvest. If the harvest is bad, the interest must still be paid in money or the farmer must forfeit real property. [...] An honest money system should derive its values from what is yielded when nature and labor work together. The role of debtor and creditor ought to be reversed. Monetary values ought to reflect the volume of production, rather than be assigned by creditors, who artificially inflate costs by adding bank charges to real values (Marsh 1998: 76-77).

Since Pound understood how usury destabilises and hinders "the nation" which he was trying to educate, he turned to a solution provided by Major C.H. Douglas' (1879-1952) Social Credit movement. These ideas, expressed in Social Credit (1918), Economic Democracy (1919), and Credit Power and Democracy (1920), initiated his "conversion experience" (qtd. in Marsh 1998: 80). Given that Douglas published his ideas in the New Age, the paper for which Pound had been writing for ten years - between 1911 and 1921 (qtd. in Marsh 1998: 80), it is highly likely that it was during these years that the poet familiarized himself with "Douglas' powerful claims for a practical simple solution to the "money issue"' (qtd. in Marsh 1998: 80).

Pound's understanding of economics, or, more specifically Douglas' Social Credit, proved to be a groundbreaking point in outlining his views of fascism. According to Leon Surette and Ellen Cardona, this shift in Pound's understanding of economics happened sometime between 1933 and 1934. "During these years," Cardona argues, "Pound met Mussolini, who he believed would carry out Social Credit reform in Italy, and also discovered another means of monetary reform through a mechanism called stamp scrip [and] read an essay by William Pelley proposing a Jewish conspiracy, which pushed him over the edge" ("Pound's Anti-Semitism at St. Elizabeths: 1945-1958"). Indeed, given that Pound strongly believed in the beneficial nature of Jeffersonian ideas and that "the American Social 
Credit Movement is frankly Jeffersonian" (Marsh 1998: 81), Pound's interest in the movement seems more than understandable.

Since Pound saw himself as a progressive teacher (as evident in his correspondence, numerous pedagogical textbooks, and his book-length epic) and strongly believed that "[ $t]$ he function of the teaching profession is to MAINTAIN THE HEALTH OF THE NATIONAL MIND" (Pound 1934b: 631), he intertwined his views of the world's problems with the poetry of The Cantos. For example, the aforementioned "Canto XLV," or the Usura Canto, as Christine Brooke-Rose pronounces it, gives the Poundian definition of the ills of the world caused by usury. Readers are provided with a note at the end of the Canto, explaining that usury refers to: "[a] charge for the use of purchasing power, levied without regard to production; often without regard to the possibilities of production" (45/230). In his "attempt to make poetry an instrument of social change" (Nicholls 1984: 1), Pound provides guidelines for reading his poetry which further instructs readers on how to approach the text. The epic, consequently, gains a textbook-like dimension, demanding a particular type of approach and suggesting to be read as educational material. Such "notes," furthermore, were not unfamiliar to Pound who offers almost a complete analysis of his translation of Li Po (or Rihaku, as he refers to the Chinese poet) in "The Jewel Stairs Grievance:"

Jewel stairs, therefore a palace. Grievance, therefore there is something to complain of. Gauze stockings, therefore a court lady, not a servant who complains. Clear autumn, therefore he has no excuse on account of weather. Also she has come early, for the dew has not merely whitened the stairs, but has soaked her stockings. The poem is especially prized because she utters no direct reproach (my emphasis, Pound 2001: 136).

"Therefore" (136) suggests that this uncommon addition to the poem is an interpretation, while "NB" and assertive sentences imply a poet-translator who suggests - or imposes - his own reading of the text. Although didactic in its intent, this strategy somewhat closes the readers' freedom to construct the poem's meaning.

Although didactic in its nature, Pound's oeuvre - even Personæ of 1909 - shows signs of a poet deeply concerned with the state of "the nation," but also a single-minded man who imposes his own, frequently selective, reading of traditions, literature, and history. What I suggest here is that it might have been precisely this inflexible stand on matters 
of economics and politics that resulted not only in his charge for treason and incarceration, but also potentially in the "closure" of The Cantos. I agree with Peter Nicholls, therefore, who argued in 1984 that: "[t]he theory of money which occupied him increasingly in later years gave the final impetus to his reversal in his thinking, leading to an authoritarian 'closure' in his poetry, and bringing about a major cleavage between ideas and material practice which ran counter to his original literary theories" (2). Pound's view of economics and politics has indeed proved to be not only a matter of grave importance to how we perceive him as a man and poet, but also to how we read his work.

While early critics - Kenner, Jackson and Schneidau, to name but three - focused mostly on Pound's experimental rhetoric in order to secure his place as a leading modernist writer and craftsman, the next generation of critics (post-1979) became increasingly interested in what Tim Redman calls "the frightening aspects of [Pound's] allegiances" (Redman 1991: 1). Critics such as Massimo Bacigalupo, Leon Surette, and Alec Marsh, on the other hand, emphasize how Pound insisted on his selective understanding of history, which eventually became manifest in his support of fascism. They further emphasize that, in Pound, "[f] ascism is a response to a specific economic order" (Morrison 1996: 48), a vehicle of economic reform which consequently framed his oeuvre.

Given that merely a few, in Pound's opinion, listened to his solutions to worldwide problems, his passion to educate "the nation" transformed into an attempt to re-educate readers by exposing them to his increasingly fanatical belief in fascism. Numerous critics have investigated Pound's view of fascism, arguing that his perception of it was unorthodox in more than one way. Peter Nicholls, for example, emphasizes that "[h]is fascism was, in short, a curious hybrid" (Nicholls 1984: 3), questioning Pound's reading of fascist agenda. In fact, Pound himself seemed a bit skeptical of fascism in a letter to Fred Miller, editor of Blast and a member of the communist party: "I claim it [fascism] is a factual method; a method practical in a certain time and place against certain inertias; and THEREFORE probably wrong in altro loco, altro tempo" (qtd. in Nicholls 1984: 80). Nicholls and Surette, moreover, highlight that in the letters of 1935 and 1936 Pound discussed fascism "with a bizarre lack of logic" (Nicholls 1984: 81). Even though skeptical towards fascism at first, the fascist and anti-Semitic content of The Cantos becomes increasingly prominent as the epic progresses. What I suggest, consequently. is that Pound, in his own insatiable desire to find 
a cure for the world's ills, selectively and "with a bizarre lack of logic" (Nicholls 1984: 81) chose to believe in particular aspects of fascism. Given that merely a few listened to his solutions to the world's ills, his passion to educate "the nation" transformed into an attempt to re-educate readers by exposing them to his increasingly fanatical belief.

Political matters became assimilated into Pound's perception of economics, which, consequently, culminated in his obsession with fascism and Mussolini, whom he considered to be a great and strong leader. Jonas Doberman reminds us that "Mussolini was in power when Pound moved to Italy and remained so until he was overthrown by Italian partisans in 1943" (Doberman 2000: 47-48), indicating the possible connection between Pound's ideas and current political situation in Italy. Given that Pound believed that he had all the answers for solving "both the worldwide economic depression of the 1930s and the oncoming war" (2000: 48), his desire to find a strong leader who would listen to what he had to say and change the world was irrevocable. Frustrated that almost no-one was listening to what he had to say after a year of trying, Pound met with Mussolini in 1933, after which he not only idealized Il Duce, but also became more committed to "the fascist cause" (qtd. in Doberman 2000: 48). After all, "Duccio came not by usura" (45/229), Pound reminds us. Looking forward to getting his hands on a microphone, as well as to gathering some money (his only income at the time were royalties and money from his father, Homer Pound), Pound applied to be a regular broadcaster at Entre Italiano Audizone Radio during the winter of 1940-1941 (Doberman 2000: 48). These almost completely incomprehensible broadcasts, which only a few listened to and even fewer understood (except for the CIA, which transcribed the speeches), provoked charges of treason against Pound. Denouncing President Roosevelt and trying to keep the US troops from taking part in the war, the radio broadcasts serve as a testimonial to Pound's megalomaniacal ideas as well as his fascist agenda. Skeptical at first, Pound's perception of fascism and Mussolini changed after he met Il Duce. Namely, Pound's dangerous obsession with Mussolini grew after Il Duce commented that The Cantos was "amusing" (qtd. in Doberman 2000: 48). It seems that this meeting drastically influenced Pound who, after Mussolini's attack of Abyssinia (that had put a stop to a form of slavery which allowed the cutting off of limbs and more grotesque kinds of mutilation), carried photographs of alleged Abyssinian atrocities which he eagerly presented to people as explanation of Mussolini's change of policy 
("Freedom Now, Or Never"). Disregarding the atrocities that took place during the attack of Abyssinia, Pound saw Mussolini as the strong leader that the world lacked. Carpenter, furthermore, emphasizes that although the interview lasted about half an hour and "had no effect whatever on Mussolini's economic policy," Pound understood that "the dictator was thoroughly sympathetic to the objective if not methods of Social Credit" (qtd. in Cardona 2008). Consequently, Massimo Bacigalupo suggests that Pound does not have a comprehensive view of history, since, "[1] acking in historical sense, he [Pound] does not realize that systems and religions are the product of complex processes that should be understood rather than judged on the basis of a few notions" (Bacigalupo 1980: 25).

Pound's idées fixes regarding sociopolitics and economics, which became inescapably obvious in the broadcasts over Rome Radio, remain a constant motif in the rest of his work reflecting his imprudent fascist, anti-Semitic, political, economic, and racial views. As Peter Nicholls notes: "Pound's political and economic ideas have in fact an intimate relation to his literary theory and practice [...] these ideas are central to it [his poetry], determining its form and content in a variety of important ways" (Nicholls 1984: 1). Indeed, as the poem progresses the "vigorous attack on economic exploitation" (Conarroe 1970: 121) transforms into his fanatical sociopolitical ideology. Bob Perelman, consequently, highlights that "we cannot divide his [Pound's] literary light [the aesthetics of The Cantos] from his Fascist light" (Pound 1970: 34). Ultimately, Pound's work of the 1950s, especially the later Cantos, is so infected with these views that Bacigalupo calls it the "sacred poem of the Nazi-Fascist millennium" (Bacigalupo 1980: x). After all, it was Pound who said to Reynolds Packard: "I believe in Fascism" (qtd. in Doberman 2000: 49) while giving a fascist salute.

The centrality of fascism to the story of The Cantos may be exhibited through an analysis of a large body of examples, but the ideograms in "Canto LIII" arguably most clearly portray this form of ideological "closure." Namely, the ideograms for "Make it New," which firstly appear in Jefferson and/or Mussolini, according to Pound stand for: "the fascist axe for the clearing away of rubbish... the tree, organic vegetable renewal. The second ideograph is the sun sign, day, "renovate, day by day renew" (qtd. in Nicholls 1984: 101). While "[t]he clearing away of rubbish" (Nicholls 1984: 101), used metaphorically yet transparently linked to Pound's deeply-rooted, anti-Semitic ideas, the idea of renewal - connected to the 
literary aspiration of "mak[ing] in new" - portrays yet another idiom of fascist ideology. As Nicholls explains, "such 'call' for constant 'renewal' [is evident] in many fascist tracts" (Nicholls 1984: 101). Interestingly, numerous volumes of Poundian correspondence (during his lifetime he wrote approximately 250,000 letters) either suggest or clearly exhibit the same fascist inclinations as The Cantos.

In "Canto LXXXIV", for example, readers witness the same attitude and almost identical syntax. Here, we learn about Pound's attempt to keep the US government from World War II by talking to government officials during his visit to Washington on the $8^{\text {th }}$ of October 1939. Written around 1945, while Pound is still in Pisa, this Canto testifies that his resentment of those who rejected to pay attention to his solutions had not disappeared, not even after - at least - six years (1939-1945).

\author{
'an' doan you think he chop an' change all the time \\ Stubborn az a mule, sah, stubborn as a MULE, \\ Got th' eastern idea about money' \\ Thus Senator Bankhead \\ 'am sure I don't know what a man like you \\ Would find to do here' \\ Said Senator Borah (84/557).
}

Pound corresponded with Senator Borah from 1933-1939, who represented his homeland - Idaho, and wanted him to be nominated by the Republican party for the 1936 presidential election. "Pound clearly hoped to be a king-maker of sorts, a gray eminence who would supply Borah with the savvy needed to beat FDR and successfully end the Great Depression while also keeping the United States out of a looming European war," Sarah C. Holmes concludes (qtd. in Cardona 2008).

The poet's attempts to convey his view on usury, economics, and politics, therefore, ended up futile ( "am sure I don't know what a man like you / Would find to do here"). The only manner of conveying those ideas was, consequently, through writing: a fact glaringly obvious both in the letters Pound sent from St. Elizabeths and The Cantos. The only form of writing elastic enough to bear his sociopolitical and economic views - the epic - thus, resembles the letters in that it resists precisely that plurality of interpretations which Pound encouraged his readers to apply. Although he was writing a "long poem containing history" (my emphasis, qtd. in 
Sicari 2005: 33), it seems that the history-related aspects were of greater importance to the epic since they caused its "closure" in terms of its form.

Although extremely prominent in the later Cantos, the fascist and antiSemitic tone has not been a feature of the early Cantos. Indeed, Massimo Bacigalupo acknowledges the shift that happens as the epic progresses, recognizing its engagement with the aesthetics in the early Cantos and the preoccupation with political and economic matters in the late Cantos. According to Bacigalupo, this change happened between 1929 and the Great Depression of the 1930s after "Pound found that one had to take sides and think about politics, economics, and history" (1980: 24). Peter Nicholls goes even further and suggests that "it is reasonable to conclude that Cantos XXI-LI remained silent about fascism in order to avoid any contact with a specific ideology" (Nicholls 1984: 94).

"Canto IV," for example, exhibits a deep engagement with aesthetics and mythology, and does not have the same sense of "closure" as the later Cantos. It abounds with aesthetically magnificent passages which are further embellished by the playful, repetitive tone. The stories it tells, however, are beautifully portrayed, even though "this canto, springs from horrors; all four of its principal stories tell of people being eaten (though Vidal is saved in the nick of time)" (Kearns 1980: 29). Pound's paratactic style offers enough room to align the stories of "people being eaten" (Kearns 1980: 29) as a succession of juxtaposed images while the repetitive tone reflects the beauty of images. What is achieved through this technique is both a sense of horror (due to the unfortunate ending of these stories) and splendor (through the masterfully crafted portrayals of mythological references which are even further emphasized by the unexpectedly cheerful tone). The sight of Diana bathing, for example, is charged with representations of Pound's aesthetic ideals while it tells the story of Actæon, who ended up "killed by his own companions and dogs" (Terrell 1993: 12). Despite the fact that this story has a tragic ending, the tone that Pound creates in this Canto by using frequent repetitions is light and playful, contributing to the overall sense of grandeur:

Actæon ...

and a valley,

The valley is thick with leaves, with leaves, the trees,

The sunlight glitters, glitters a-top, 
Not a ray, not a sliver, not a spare disc of sunlight

Bathing the body of nymphs, of nymphs, and Diana,

Nymphs, white-gathered about her, and the air, air (my emphasis, 4/14).

The tone of this Canto, furthermore, stands in stark contrast to the tone of the sections which discuss fascism and anti-Semitism. The "openness" of form which allows Pound to make both horror and splendor themes of this Canto, is lost in the assertive and aggressive tone of the later Cantos.

This paper has tried to portray how the ideas showing the "delusional nature of his beliefs" (Doberman 2000: 49), already evident in Guide to Kulchur, radically influenced the poetry of The Cantos turning it into a closed, fascist manifesto. These beliefs gradually changed, moulding the aesthetic beauty of the early Cantos into an aggressive tone of the later segments. Fascism acts an educational tool in the later Cantos influencing both the form and content of the epic, ultimately resulting in the loss of the plurality of interpretations. The "idealization of the past" (Zox-Weaver 2011: 7), as Zox-Weaver pronounces it, which results in the modernists' tendency to narrow their circle of readers to "a coterie of sophisticated readers" (2011: 59), had far-reaching consequences in Pound's work. His view of the past not only limited his readership, but it also caused the "closure" of the poem. This ultimately shifted the focus of the opening Canto - the translation into Anglo-Saxon prosody from a Renaissance-Latin rendering of an epic - to the "sacred poem of the Nazi-Fascist millennium" (Bacigalupo 1980: x).

\section{References}

Albright, D. (1999). "Early Cantos I-XLI." In: Ira B Nadel (ed.), The Cambridge Companion to Ezra Pound. Cambridge: Cambridge University Press, 59-91.

Alexander, M. J. (1979). The Poetic Achievement of Ezra Pound. Boston: Faber and Faber.

Axelrod, G. S. R. Travisano (2005). The New Anthology of American Poetry: Modernisms, 1900-1950. New Brunswick, N.J.: Rutgers University Press. 
Bacigalupo, M. (1980). The Forméd Trace: The Later Poetry of Ezra Pound. New York: Columbia University Press.

Bettridge, J. (2005). "Make It New." In: Demetres P. Tryphonopoulos and Stephen J. Adams (eds.) . The Ezra Pound Encyclopedia. London: Greenwood Press, 190-191.

Bloch, E, et al. (1977). Aesthetics and Politics. London, NLB.

Bornstein, George. (2001). Material Modernism: The Politics of the Page. Cambridge: Cambridge University Press.

Bosha, F. J. (1990). "Hemingway and MacLeish on Pound: A Consideration of Certain Unpublished Correspondence." Paideuma, 19.3, 133-38.

Bush, R. (1995). "Modernism, Fascism, and the Composition of Ezra Pound's Pisan Cantos." Modernity/Modernism, 2.3, 69-87.

Cardona, E. (2008). "Pound in Italy, 1924-1939: The Progression of Pound's Anti-Semitism," Flash point, Web Issue 11. 9 June 2012.

Casillo, R. (1988). The Genealogy of Demon: Anti-Semitism, Fascism, and the Myths of Ezra Pound. Evanston: Northwestern University Press.

Conarroe, J. (1970). William Carlos Williams' Paterson: Language and Landscape. Philadelphia: University of Pennsylvania Press.

Cookson, W. (1985). A Guide to The Cantos of Ezra Pound. New York: Persea Books.

De Rachewiltz, M. (1975). Ezra Pound, Father and Teacher: Discretions. New York: New Directions.

Doberman, J. (2000). "The Treason Debate: Ezra Pound and His Rome Radio Broadcasts." The Concord Review, 45-66.

Donaldson, S. \& R. H. Winnick (1992). Archibald MacLeish: An American Life. Boston: Houghton Mifflin.

Doob, L. W. (ed) (1978). "Ezra Pound Speaking":Radio Speeches of World War II. Westport, Conn: Greenwood Press.

Ellis, H. E. and B. A. Drabeck with Margaret E.C. Howland (1995). Archibald MacLeish: A Selectively Annotated Bibliography. Lanham, Md.: Scarecrow Press.

Froula, C. (1983). A Guide to Ezra Pound's Selected Poems. New York: New Directions.

Hatlen, B. (1995). "Ezra Pound and Fascism." In: Marianne Korn (ed.), Ezra Pound and History. Orono, Maine: The National Poetry Foundation, 145-72.

Hartley, G. (2006). "Under the Sign of Paideuma: Scary Ideiograms \& the New Fascisms." Paideuma, 35.3, 25-34. 
Hénault, M. (1971). The Merrill Studies in The Cantos. Columbus, Ohio: C. E. Merrill Pub. Co.

Jackson, T. H. (1969). The Early Poetry of Ezra Pound. Cambridge: Harvard University Press.

Kadlec, D. (2000). Mosaic Modernism: Anarchism, Pragmatism, Culture. Baltimore: Johns Hopkins University Press.

Kearns, G. (1980). Guide to Ezra Pound's Selected Cantos. Folkestone: Dawson.

Kenner, H. (1951). The Poetry of Ezra Pound. New York: New Directions.

(1961). "The Broken Mirrors and the Mirror of Memory." In:

Lewis Leary (ed.), Motive and Method in the Cantos of Ezra Pound. N.J.: Columbia University Press, 3-32.

Press.

(1971) The Pound Era. Berkeley: University of California

Laughlin, J. (1986). The Master of Those Who Know: Ezra Pound. San Francisco: City Lights Books.

(1987). Pound as Wuz: Essays and Lectures on Ezra Pound. Saint Paul: Graywolf Press.

(2005). Byways: a Memoir. Peter Glassgold (ed.). New York: New Directions.

Levenson, M. H. (1998). The Cambridge Companion to Modernism. Cambridge: Cambridge University Press.

(1984). A Genealogy of Modernism: A Study of English Literary Doctrine, 1908-1922. Cambridge: Cambridge University Press.

MacLeish, A. (1986). A Continuing Journey. Boston: Houghton Mifflin.

"Archibald MacLeish Collection." Beinecke Rare Book and Manuscript Library, New Haven, CT. (YCAL MSS 38).

"Archibald MacLeish Collection." Beinecke Rare Book and Manuscript Library, New Haven, CT. (YCAL MSS 269).

Archibald MacLeish: Letters 1907-1982. (1983). R. H. Winnick (ed.). Boston: Houghton Mifflin.

"Pound, Ezra, 1885-1972--Correspondence." "Archibald MacLeish Papers." Manuscript Division, Library of Congress, Washington, D.C. (MSS30932).

Houghton Mifflin.

(1978). Riders on the Earth: Essays and Recollections. Boston: (1980). Six Plays. Boston: Houghton Mifflin Co. 
Marsh, A. (1998). Money and Modernity: Pound, Williams, and the Spirit of Jefferson. Tuscaloosa, AL: University of Alabama Press.

McDonald, G. (1993). Learning to be Modern: Pound, Eliot, and the American University. Oxford: Clarendon Press.

Meacham, H. M. (1967). The Caged Panther: Ezra Pound at St. Elizabeths. New York: Twayne.

Morrison, P. (1996). The Poetics of Fascism: Ezra Pound, T.S. Eliot, Paul de Man. New York: Oxford University Press.

Mullins, E. (1954). The Federal Reserve Conspiracy. Union, N.J.: Common Sense.

Nadel, I. B. (ed.) (2007). The Cambridge Introduction to Ezra Pound. Cambridge: Cambridge University Press.

(2010). Ezra Pound in Context. Cambridge: Cambridge

University Press.

Nicholls, P. (1984). Ezra Pound: Politics, Economics and Writing. New York: Macmillan.

North, M. (1991). The Political Aesthetic of Yeats, Eliot, and Pound. New York: Cambridge University Press.

(1999). Reading 1922: A Return to the Scene of the Modern. New York: Oxford University Press.

Pearce, R. H. (1963). "Pound, Whitman, and the American Epic." In: Walter Sutton (ed.), Ezra Pound, A Collection of Critical Essays. Prentice-Hall: Englewood Cliffs, 163-177.

Perelman, B. (1994). The Trouble with Genius: Reading Pound, Joyce, Stein, and Zukofsky. Berkeley: University of California Press.

Perloff, M. (1985). The Dance of the Intellect: Studies in the Poetry of the Pound Tradition. New York: Cambridge University Press.

Pound, E. (1934). ABC of Reading. New York: New Directions. 630-635.

(1934). "The Teacher's Mission." The English Journal, 23.8,

(1948). The Cantos of Ezra Pound. New York: New Directions.

(1954). Literary Essays. London: Faber and Faber.

(1970). Guide to Kulchur. New York: New Directions.

(1970). Jefferson and/or Mussolini. New York: Liveright.

(1971). How to Read. New York: Haskell House.

(1973). Selected Prose, 1909-1965. William Cookson (ed.).

New York: New Directions.

(2001). Personae. London: Faber. 
(2007). Ezra Pound's Economic Correspondence, 1933-1940. Roxana Preda (ed.). Gainesville: University Press of Florida.

Pound, O. and R. Spoo (eds.) (1999). Ezra and Dorothy Pound: Letters in Captivity. 1945-1946. Oxford: Oxford University Press.

Qian, Z. (2005). "Cathay." In: Demetres P. Tryphonopoulos and Stephen J. Adams (eds.), The Ezra Pound Encyclopedia. London: Greenwood Press, 53-54.

Quinn, M. B. (1954). “The Metamorphoses of Ezra Pound.” In: Lewis Leary (ed.), Motive and Method in The Cantos of Ezra Pound. New York: Columbia University Press, 60-100.

Rainey, L. (1991). Ezra Pound and the Monument of Culture: Text, History, and the Malatesta Cantos. Chicago: University of Chicago Press.

(1998). Institutions of Modernism: Literary Elites and Public Culture. New Haven: Yale University Press.

Redman, T. (1991). Ezra Pound and Italian Fascism. New York: Cambridge University Press.

Rosenthal, M. L. (ed.) (1966). The William Carlos Williams Reader. New York: New Directions.

Ruthven, K. K. (1983). A Guide to Ezra Pound's Personae (1926). Berkeley, London: University of California Press.

(1990). Ezra Pound as Literary Critic. London: New York: Routledge.

Selby, N. (2005). Poetics of Loss in the Cantos of Ezra Pound: From Modernism to Fascism. Lewiston, NY: Mellen Press.

Schneidau, H. N. (1969). Ezra Pound: The Image and the Real. Baton Rouge: Louisiana State University Press.

Sicari, S. (2005). "The Cantos: The Fifth Decad of Cantos XLII-LI." In: Demetres Press. Tryphonopoulos and Stephen J. Adams, The Ezra Pound Encyclopedia. London: Greenwood Press.

Stoicheff, P. (1995). The Hall of Mirrors: Drafts \& Fragments and the End of Ezra Pound's Cantos. Michigan: University of Michigan Press.

Surette, L. (1993). The Birth of Modernism: Ezra Pound, T.S. Eliot, W.B. Yeats, and the Occult. Montreal: McGill-Queen's University Press.

and Demetres P. Tryphonopoulos (eds.) (1996). Literary Modernism and the Occult Tradition. Orono, Maine: The Nsational Poetry Foundation.

(1999). Pound in Purgatory: From Economic Radicalism to AntiSemitism. Chicago: University of Illinois Press. 
Sweet, H. (1959). Anglo-Saxon Reader in Prose and Verse. Oxford: Clarendon Press.

Terrell, C. F. (1993). . A Companion to The Cantos of Ezra Pound. Berkeley; London: University of California Press in cooperation with the National Poetry Foundation, University of Maine at Orono.

Tremblay, T. (2005). “Frobenius, Leo (1873-1938).”In: D. P. Tryphonopoulos, and S. J. Adams, The Ezra Pound Encyclopedia. London: Greenwood Press, 126-127.

Tryphonopoulos, D. P. (1992). The Celestial Tradition: A Study of Ezra Pound's The Cantos. Waterloo, Ontario: Wilfrid Laurier University Press.

Willmott, G. (2002). Unreal Country: Modernity in the Canadian Novel in English. Montreal: McGill-Queen's University Press.

Witemeyer, H. (ed.). (1996). Pound/Williams: Selected Letters of Ezra Pound and William Carlos Williams. New York: New Directions.

Xie, M. (1999). "Pound as Translator." In: Ira B. Nadel (ed.), The Cambridge Companion to Ezra Pound. Cambridge: Cambridge University Press, 204-223.

Zox-Weaver, A. (2011). Women Modernists and Fascism. Cambridge: Cambridge University Press.

Received: 1 September, 2012

Accepted for publication: 15 September, 2012

Светлана Недељков

\section{ОД ЕКОНОМИЈЕ ДО ФАШИЗМА: ПРОМЕНА КА ИНКЛУЗИВНОСТИ ЕЗРЕ ПАУНДА}

\section{Сажетак}

Књижевни активиста Езра Паунд посветио је свој живот писању, превођењу и подучавању оних који су наклоњени стварању у духу модерне. Са друге стране Паунд је песник мегаломанијачких идеја, верујући да се свет може променити подучавањем „нације“. Тражећи решење текућим друштвено-политичким проблемима, Паунд у одређеном тренутку почиње да поистовећује Јевреје са зеленашењем и сматра их узрочницима многобројних светских проблема. Овај став га је, коначно и приближио фашизму. Циљ овог рада је, стога, да истражи како Паундова намера да 
образује читаоце прераста у жељу да се читалаштво поново подучи; да ли еп Песме, који је Паунд започео као естетски и семантички „отворен“ текст прераста у „затворен“ фашистички манифест оцртавајући Паундов политички став?

Кључне речи: Езра Паунд, Песме, педагогија, фашизам, „отворени“ и „затворени“"текст. 